\title{
EFFECT OF IRRIGATION INTERVALS AND ORGANIC AND MINERAL FERTILIZATION SYSTEMS ON PRODUCTIVITY AND QUALITY OF HYBRID RICE
}

\author{
M. E. Ibrahim ${ }^{(1)}$, S. A El-Shamarka ${ }^{(1)}$, I. S. El-Refaee ${ }^{(2)}$, O. A. M. Ali ${ }^{(1)}$ \\ and I. A. Sheta ${ }^{(2)}$ \\ (1) Crop Science Depart., Fac. of Agric., Menoufia University, Egypt \\ (2) Agric. Res. Center, Field Crops Res. Inst., Rice Res. \& Train. Center, 33717 Sakha - Kafr El- \\ Sheikh, Egypt
}

Received: Mar. 14, 2017

Accepted: Apr. 8, 2017

\begin{abstract}
ABSTERACT: Two field experiments were conducted at the Experimental Farm of Rice Research and Training Center (RRTC), Sakha, Kafr El-Sheikh, Egypt during 2011 and 2012 seasons to investigate the effect of irrigation intervals, organic and mineral fertilization on the growth, grain yield, technological characteristics of grains and some water relations of two hybrid rice genotypes. A split split-plot design with three replicates was used. The main plots were devoted to four irrigation treatments namely, continuous flooding (CF), irrigation every 6 days (6-day), irrigation every 8 days (8-day), irrigation every 10 days (10-day). The sub plots were occupied by two hybrid rice genotypes namely; Egyptian hybrid rice one (EHR1) and SK2046H hybrid rice (SK2046H). However, the sub-sub plots were consisted of organic and mineral fertilization as follows: ( $\left.T_{1}\right)$ zero fertilizer (control), ( $\left.T_{2}\right) 160 \mathrm{~kg} \mathrm{~N}+40 \mathrm{~kg} \mathrm{P}_{2} \mathrm{O}_{5}+60 \mathrm{~kg}$ $\mathrm{K}_{2} \mathrm{O} / \mathrm{ha}$ (recommended level), ( $\left.T_{3}\right)$ compost (5 t/ha), ( $\left.T_{4}\right) 40 \mathrm{~kg} \mathrm{~N}+10 \mathrm{~kg} \mathrm{P}_{2} \mathrm{O}_{5}+15 \mathrm{~kg} \mathrm{~K} \mathrm{~K}_{2} \mathrm{O} / \mathrm{ha}$ + compost (5 t/ha), ( $\left.T_{5}\right) 80 \mathrm{~kg} \mathrm{~N}+20 \mathrm{~kg} \mathrm{P} \mathrm{O}_{5}+30 \mathrm{~kg} \mathrm{~K}{ }_{2} \mathrm{O} / \mathrm{ha}+$ compost (5 t/ha), ( $\left.T_{6}\right) 120 \mathrm{~kg} \mathrm{~N}$ $+30 \mathrm{~kg} \mathrm{P}_{2} \mathrm{O}_{5}+45 \mathrm{~kg} \mathrm{~K} \mathrm{O}_{2} \mathrm{ha}+$ compost (5 t/ha) and $\left(\mathrm{T}_{7}\right) 160 \mathrm{~kg} \mathrm{~N}+40 \mathrm{~kg} \mathrm{P}_{2} \mathrm{O}_{5}+60 \mathrm{~kg} \mathrm{~K}{ }_{2} \mathrm{O}$ /ha + compost (5 t/ha). The results obtained could be summarized as follows: The data indicated that CF followed by 6-day recorded the highest values of grain yield and its components (number of panicles $/ \mathrm{m}^{2}$, panicle length, number of total grains/ panicle, sink capacity, panicle density, 1000-grain weight, panicle weight, grain, straw and biological yields/ha as well as harvest index), grain quality (hulling, milling and head rice percentages) and grain chemical analysis (N, $P, K$ and protein percentage). On the other hand, irrigation every 10 days recorded the highest values of days to heading, unfilled grains and broken rice percentages in both seasons. EHR1 genotype recorded the highest values of grain yield, grain yield components, grain quality and chemical analysis of grains. However, SK2046H genotype recorded the highest values of panicle length and unfilled grains and broken rice percentages in both seasons. Fertilization treatments had a marked effect on characteristics studied in favor of fertilization treatments of $T_{7}, T_{2}$ and $T_{6}$ which gave the highest values of grain yield, grain yield components, grain quality and chemical analysis of grains. However, unfertilized plants (T1) gave the lowest values of most characteristics studied. It can be concluded that it is possible using the irrigation system every 6 days with the application of mineral fertilizer of $120 \mathrm{~kg} \mathrm{~N}+$ $30 \mathrm{~kg} \mathrm{P}_{2} \mathrm{O}_{5}+45 \mathrm{~kg} \mathrm{~K} \mathrm{O}_{2} \mathrm{ha}+$ organic fertilizer of compost (5 t/ha) for saving some amounts of irrigation water by about $10 \%$ as well as mineral fertilizer of NPK by about $25 \%$ with insignificant and minimum reduction in grain productivity of hybrid rice genotypes.
\end{abstract}

Key words: Hybrid rice, irrigation, water productivity, organic and mineral fertilization.

\section{INTRODUCTION}

Rice (Oryza sativa L.) is one of the most important food crops in the world. A wide section of society is greatly influenced by rice growing. Rice is a basic food for the majority of world population in their daily meals. Moreover, it is a major source of national income and a basic component of a 
number of industries. Thus, efforts are required to increase grain yield of rice per unit area to meet food requirements of over growing population. For higher grain yield, it is necessary to develop irrigation treatments and fertilization systems. Water is the most important single component of sustainable rice production. Rice is grown in lowland areas under flooded conditions. In Egypt, farmers resort to continuous flooding resulting in an enormous wastage of water and lower water use efficiency the development of water saving technologies through: increasing irrigation intervals without any drastic reduction on grain yield, growing drought tolerant genotypes, which have capability to grow under shortage of water, improve soil properties by development characteristics of saving moisture.

The hybrid rice research program in Egypt was restarted in 1995 (Bastawisi et al., 1998). The program resulted in the development of two promising hybrid rice genotypes, i.e SK2034H (Egyptian hybrid rice 1) and SK2046H, which outyielded the current cultivars by $15-30 \%$ (Bastawisi et al., 2005).

In recent years, chemical fertilizers have widely spread throughout the world, fertilizer cost and concern for sustainable soil productivity and ecological stability, in relation to chemical fertilizer use, has emerged as an important issue (Aulakh and Singh, 1997). However, it is now realized that, in fields under intensive monoculture, which receive heavy applications of chemical fertilizers alone, there is a slow decline in productivity. This decline occurs even in irrigated paddy fields (FFTC, 1998). Sustainability in crop yield and soil health could be achieved by the application of mineral fertilizers, along with organic fertilizers. (Dobermann and Fairhurst, 2002) reported that rice straw was the organic material available in significant quantities to most rice farmers. About $40 \%$ of the N, 30$35 \%$ of the $\mathrm{P}, 80-85 \%$ of the $\mathrm{K}$ and $40-50 \%$ of the sulfur (S), taken up by rice remains in their vegetative plant parts at crop maturity. Therefore, use of rice straw compost in agriculture has been an increased interest due to the possibility of recycling valuable components. The application of organic materials, like farmyard manure, poultry manure and residual crops compost are fundamentally important in supply various kinds of plant nutrients, improve soil physical and chemical properties and, hence, nutrient holding and buffering capacity, as well as, consequently, enhance microbial activities (Raikar, 2007). In addition, organic matter, continuously, release $\mathrm{N}$ as plant needs it. $\mathrm{N}$ is the most limiting nutrient in irrigated rice systems, but, $\mathrm{P}$ and $\mathrm{K}$ deficiencies are, also, the constraints increasing grain yield for consecutive planting of rice. An advantage of farm application of organic materials is that they usually provide a number of nutritive elements to crops with little added cost. Experience in tropical Asian countries, generally, shows that organic farming alone does not supply enough nutrients and organic fertilizers need to be supplemented by a basal dressing of chemical fertilizer (Siavoshi et al., 2011). Also Prasad and Sinha (2000) found that the application of farmyard manure (FYM) or FYM + crop residues could substitute $50 \%$ NPK for wheat production and their residual effect was equivalent to $50 \%$ of the recommended dose of NPK, as a chemical fertilizer on grain yield of succeed rice crop. To meet the current shortage of chemical fertilizers, caused by energy crisis and socioeconomic constraints, it has become desirable to conserve crop residues and organic manure and recycles them into the soil to increase the efficiency of soil nutrients. Where water is more limiting than land, it has been argued that water productivity becomes more important than yield or land productivity (Tuong and Bouman, 2003). Substantial yield and water productivity grains are possible with the application of appropriate nutrients in combination with 
optimum water management adapted to the target environments.

The objective of the present study is to evaluate the response of hybrid rice genotypes to organic and mineral fertilization under different irrigation intervals

\section{MATERIALS AND METHODS}

Two field experiments were conducted at the Experimental Farm of Rice Research and Training Center (RRTC), Sakha, Kafr El-Sheikh, Egypt during 2011 and 2012 seasons to investigate the effect of irrigation intervals, organic and mineral fertilization on the growth, grain yield, technological characteristics of grains and some water relations of two hybrid rice genotypes. Each experiment included 56 treatments which were the combination of four irrigation intervals, two rice genotypes and seven fertilization systems. The tested experimental treatments are as follows:-

(A) Irrigation intervals : continuous flooding (CF), irrigation every 6 days (6-day), 8 days (8-day) and 10 days (10-day)

(B) Rice genotypes : Egyptian hybrid rice one (EHR1) and SK2046H hybrid rice (SK2046H)

(C) Fertilization systems i.e. $\left(T_{1}\right)$ zero fertilizer (control), ( $\left.\mathrm{T}_{2}\right) 160 \mathrm{~kg} \mathrm{~N}+40 \mathrm{~kg}$ $\mathrm{P}_{2} \mathrm{O}_{5}+60 \mathrm{~kg} \mathrm{~K} \mathrm{~K} / \mathrm{ha}$ (recommended level), ( $\left.\mathrm{T}_{3}\right)$ compost (5 t/ha), ( $\left.\mathrm{T}_{4}\right) 40 \mathrm{~kg} \mathrm{~N}$

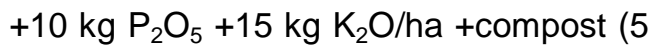
t/ha), $\left(\mathrm{T}_{5}\right) 80 \mathrm{~kg} \mathrm{~N}+20 \mathrm{~kg} \mathrm{P}_{2} \mathrm{O}_{5}+30 \mathrm{~kg}$ $\mathrm{K}_{2} \mathrm{O} / \mathrm{ha}+$ compost (5 t/ha), $\left(\mathrm{T}_{6}\right) 120 \mathrm{~kg} \mathrm{~N}$ $+30 \mathrm{~kg} \mathrm{P} \mathrm{O}_{5}+45 \mathrm{~kg} \mathrm{~K} 2 \mathrm{O} / \mathrm{ha}+$ compost (5 t/ha) and $\left(\mathrm{T}_{7}\right) 160 \mathrm{~kg} \mathrm{~N}+40 \mathrm{~kg} \mathrm{P}_{2} \mathrm{O}_{5}+$ $60 \mathrm{~kg} \mathrm{~K}{ }_{2} \mathrm{O} / \mathrm{ha}+$ compost (5 t/ha).

In both seasons, split split-plot design, with three replicates, was used, where the main plots were devoted to irrigation intervals and the sub plots were occupied by rice genotypes, While, the sub sub-plots were allocated to the fertilizers treatments.

The two tested rice genotypes were obtained from rice research and training center Sakha Kafr El-Sheikh, Agricultural Research Center, Ministry of Agriculture. Description of the two tested rice genotypes herein presented in Table (1)

All experiments were preceded by wheat (Triticum aestivum L.). The experimental soil was clay and the chemical analysis is shown in Table (1). Compost fertilizer was prepared at the Gemmiza Agricultural Research Station using organic materials and subsequently applied and incorporated into dry soil of plots. The chemical composition of the compost used in the two growing seasons are presented in Table (2).

Table (1): characteristics of the studied rice genotypes

\begin{tabular}{|c|c|c|c|c|}
\hline Genotypes & Pedigree & Type & Duration (day) & Grain type \\
\hline EHR1 & IR 69625A/ Giza 178 & Indica / japonica & 135 & Medium \\
\hline SK 2046 H & IR 69625A/ Giza 181 & Indica / japonica & 135 & Medium long \\
\hline
\end{tabular}

Table (2): Chemical properties of the experimental sites before planting in 2011 and 2012 seasons and chemical composition of used rice straw compost.

\begin{tabular}{|c||c|c||c|c|}
\hline \multicolumn{2}{|c||}{ Soil } & \multicolumn{2}{c|}{ Composted rice straw } \\
\hline Properties & 2011 & 2012 & Properties & Value \\
\hline \hline $\mathrm{pH}$ & 7.8 & 8.0 & $\mathrm{C}(\%)$ & 26.8 \\
Organic matter (\%) & 1.70 & 1.60 & $\mathrm{~N}(\%)$ & 1.07 \\
Available N (ppm) & 17 & 19 & $\mathrm{C} / \mathrm{N} \mathrm{ratio}$ & 25.04 \\
Available P ppm & 14 & 15 & $\mathrm{P}(\%)$ & 0.37 \\
Available K ppm & 311 & 320 & $\mathrm{~K}(\%)$ & 0.60 \\
Available Zn ppm & 0.8 & 0.9 & $\mathrm{Zn}(\mathrm{ppm})$ & 51 \\
\hline
\end{tabular}


Rice grains as recommended rates for hybrids (24 kg grains/ha) were soaked in fresh water for 24 hours and further incubated for another 48 hours to enhance germination. Grains were sown in $10^{\text {th }}$ and $12^{\text {th }}$ May in 2011 and 2012 seasons, respectively The experimental field was identified and well prepared by two plowing and harrowing then, carefully dry leveled. The area of sub sub-plot was $20 \mathrm{~m}^{2}(4 \times 5$ $\mathrm{m})$. Each plot was fertilized, according to the rate of each treatment, with phosphorus as calcium superphosphate $\left(15.5 \%, \mathrm{P}_{2} \mathrm{O}_{5}\right)$ was added during land preparation. The potassium fertilizer as potassium sulfate $\left(48 \%, \mathrm{~K}_{2} \mathrm{O}\right)$ was added half dose as basal and other half at panicle initiation. Nitrogen fertilizer as Urea $(46.5 \%, \mathrm{~N})$ was applied in three equal splits (at basal, top dressing at maximum tillering and panicle initiation).

To avoid the lateral movement of water and more water control, each main plot was separated by wide ridge, 4 meter width, as a border. Water pump, provided with a calibrated water meter, was used for all water measurements.

At harvest (135 days after sowing, DAS) number of panicles $/ \mathrm{m}^{2}$ were estimated. Ten randomly panicles were collected from each sub sub-plot to estimate panicle length (cm), number of total grains/panicle, number of filled grains/panicle, panicle weight (g) and 1000 -grain weight $(\mathrm{g})$. Grain and straw yields ( $t / h a)$ were measured from area of 9 $\mathrm{m}^{2}(3 \times 3 \mathrm{~m})$ and grain yield was adjusted to $14 \%$ moisture content.

About 150 grams of paddy grains were taken from each sub sub-plot and transferred to the seed technology laboratory of RRTC to determine some of grain quality (hulling, milling, head rice and broken rice percentage) characteristics according to the methods described by Juliano (1971) and Khush et al. (1979).

After harvest, grain samples were taken and then dried at $70 \mathrm{C}^{\circ}$ for 48 hours until the weight was fixed. Dried samples of milled rice were taken to determine the following chemical analysis:- Nitrogen (\%) was determined by the micro Kjeldahl method described by AOAC (1970), phosphorus (\%) was determined calorimetrically by ascorbic acid method according to Watanable and Olsen (1965) and potassium (\%) was determined using flame photometer as described by Jackson (1967). However, crude protein was estimated by multiplying total nitrogen (\%) by the factor of 5.95 .

Water pump, provided with a calibrated water meter, was used for irrigation to calculate the total water used and water saved was calculated. Water productivity (WP) was calculated as the weight of grains per unit of water used ( $\mathrm{kg}$ grains $/ \mathrm{m}^{3}$ water).

The analysis of variance was carried out according to Gomez and Gomez (1984). Treatment means were compared by Duncan's Multiple Rang Test (Duncan, 1955). Statistical analysis of variance was done using COSTAT software package.

\section{RESULTS AND DISCUSSION 1- Grain yield and its component:}

Data presented in Table (3) showed that number of panicles $/ \mathrm{m}^{2}$, number of total grains/panicle, 1000-grain weight, panicle weight and grain yield ( $\mathrm{t} / \mathrm{ha}$ ) were significantly increased by using continuous flooding irrigation system followed by irrigation every 6 days without significant differences between them. However, panicle length and straw yield ( $t / h a$ ) were significantly increased under continuous flooding irrigation system followed by irrigation every 6 days. On the other hand, irrigation every 10 days caused a reduction in aforementioned characteristics and recorded the highest values of unfilled grains (\%) in both seasons. The increasing of grain yield /ha with continuous flooding system could be ascribed to the increase in the grain yield components, i.e. number of panicles $/ \mathrm{m}^{2}$, panicle weight and 1000 grain weight. In addition, such results might be interpreted by the fact that available water 


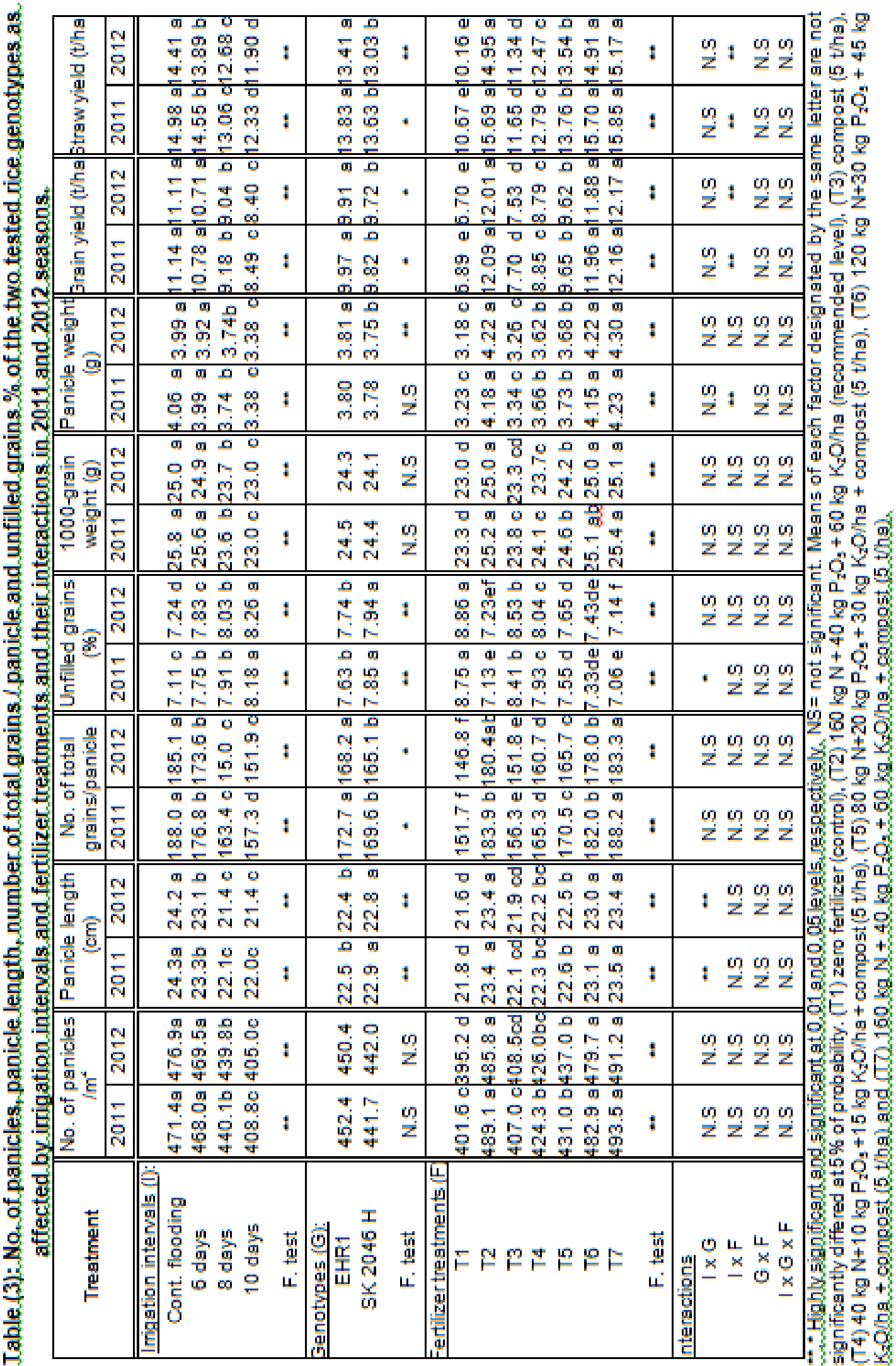


enhanced the production and transportation of the dry matter content to panicles, resulting in more grain filling and weight, as well as, higher grain yield (El-Refaee, 2012). However, increasing grain yield /ha with irrigation every 6 days might be due to better aeration and root system associated with higher mobility and absorption of inorganic NPK in soil solution, which increased the uptake of nutrients. These results are in harmony with the results obtained by ElRefaee (2002), Ghazy (2010) and El-Refaee (2012).

Data in Table (3) indicated that EHR1 genotype recorded the maximum values of total number of grains per panicle, grain and straw yields (t/ha), in both seasons. Also, EHR1 recorded the maximum values of panicle weight in 2012 season compared to SK2046H hybrid genotype, which produced the maximum values of panicle length and unfilled grains (\%), these results are fairly true in both seasons. The same results were obtained by Ghazy (2010) and El-Refaee et al (2012). Also, Sheta (2010) found that unfilled grains of rice plants was differed in some rice varieties such as Giza178, Sakha104, Sk2058H and EHR1.

Results in Table (3) indicated that the number of panicles $/ \mathrm{m}^{2}$, panicle length, number of total grains/panicle, number of filled grains /panicle, 1000-grain weight, panicle weight, grain and straw yields was significantly affected by different tested fertilizer treatments. In both seasons, application fertilizer as $T_{7}, T_{2}$ and $T_{6}$ gave the highest significant values of all above traits, without any significant differences among them. However, the control treatment $\left(T_{1}\right)$ gave the lowest values of those characteristics and recorded the highest values of unfilled grains (\%), in both seasons. The superiority grain yield with $\mathrm{T}_{2}$, $T_{6}$ and $T_{7}$ treatments, could be a scribed to the increase in grain yield attributes. Also, such results might be interpreted by the fact that available nutrients enhances the production and transportation of the dry matter content to panicles, resulting in more grain filling and weight, as well as, high grain yield. Similar finding were reported by ElRefaee (2012).

The interaction between the tested irrigation intervals and genotypes was significantly affected on panicle length in 2011 and 2012 seasons (Table 4). The highest values of panicle length were obtained when SK2046H plants were irrigated with CF system, in both seasons. On the contrary, the irrigation system 10-day recorded the lowest and significant values of panicle length with both SK2046H and EHR1. These results are true in the two growing seasons. Data, also, revealed that SK2046H genotype recorded the highest values of unfilled grains (\%) under irrigation system every 10 days. While, plants of SK2046H and EHR1 recorded the lowest values of unfilled grains (\%) under continuous flooding irrigation system in 2011 season.

The interaction between irrigation intervals and fertilizer treatments was highly significant for grain and straw yields /ha in both seasons, (Table 5). The data show that the plants irrigated with CF system and fertilized with $T_{7}$ treatment produced the maximum grain yield /ha followed by $T_{2}$ and $\mathrm{T}_{6}$ without significant reduction in grain yield/ha among them in both seasons. The same trend was found under irrigation every 6 days. However, the plants irrigated every 10 days without fertilization $\left(T_{1}\right)$ gave the lowest grain yield in both seasons. Also, the interaction between irrigation intervals and fertilizer treatments was highly significant for panicle weight in 2011 season. Data indicated that the plants irrigated with $\mathrm{CF}$ system or 6-day and fertilized with $\mathrm{T}_{7}$ treatment produced the maximum panicle weight followed by $T_{2}$ and $T_{6}$ without significant differences among them. However, the plants irrigated every 10 days without fertilization $\left(T_{1}\right)$ gave the lowest panicle weight in 2011 season. Similar results were found by El-Saka (2013) and Ghazy (2015). 
Table (4): Panicle length and unfilled grains percentage as affected by the interaction between irrigation intervals and genotypes.

\begin{tabular}{|c|c||c|c|c|c|}
\hline \multirow{2}{*}{ Season } & \multirow{2}{*}{ Genotypes } & \multicolumn{5}{c|}{ Irrigation intervals } \\
\cline { 3 - 6 } & & Cont. flooding & 6 days & 8 days & 10 days \\
\hline \hline \multicolumn{6}{|c|}{ Panicle length (cm) } \\
\hline \multirow{2}{*}{2011} & EHR1 & $23.9 \mathrm{~b}$ & $23.0 \mathrm{c}$ & $21.7 \mathrm{~d}$ & $21.4 \mathrm{~d}$ \\
& SK 2046 H & $24.7 \mathrm{a}$ & $23.7 \mathrm{~b}$ & $21.7 \mathrm{~d}$ & $21.3 \mathrm{~d}$ \\
\hline \multirow{2}{*}{2012} & EHR1 & $23.8 \mathrm{~b}$ & $22.8 \mathrm{c}$ & $21.6 \mathrm{~d}$ & $21.4 \mathrm{~d}$ \\
& SK 2046 H & $24.5 \mathrm{a}$ & 23.6 & $21.6 \mathrm{~d}$ & $21.3 \mathrm{~d}$ \\
\hline \hline \multicolumn{7}{|c|}{ Unfilled grains (\%) } \\
\hline \multirow{2}{*}{2011} & EHR1 & $7.11 \mathrm{e}$ & $7.61 \mathrm{~d}$ & $7.72 \mathrm{~d}$ & $8.06 \mathrm{~b}$ \\
& SK 2046 H & $7.11 \mathrm{e}$ & $7.90 \mathrm{c}$ & $8.09 \mathrm{~b}$ & $8.30 \mathrm{a}$ \\
\hline \hline
\end{tabular}

Means of each factor designated by the same letter are not significantly different at $5 \%$ level of probability according to Duncan's Multiple Rang Test.

Table (5): Panicle weight (g), grain and straw yields ( $\mathrm{t} / \mathrm{ha}$ ) as affected by the interaction between irrigation intervals and fertilizer treatment in 2011 and 2012 seasons.

\begin{tabular}{|c|c|c|c|c|c|c|c|c|}
\hline \multirow{2}{*}{ Season } & \multirow{2}{*}{$\begin{array}{l}\text { Irrigation } \\
\text { intervals }\end{array}$} & \multicolumn{7}{|c|}{ Fertilizer treatments } \\
\hline & & $\mathrm{T} 1$ & T2 & T3 & $\mathrm{T} 4$ & T5 & T6 & T7 \\
\hline \multicolumn{9}{|c|}{ Panicle weight (g) } \\
\hline \multirow{4}{*}{2011} & CF & 3.38 hijk & $4.55 \mathrm{ab}$ & 3.46 hijk & 3.90 cdef & 3.98 cde & $4.53 \mathrm{ab}$ & $4.61 \mathrm{a}$ \\
\hline & 6 days & 3.30 hijk & $4.48 \mathrm{ab}$ & $3.41 \mathrm{hjk}$ & 3.83 defg & 3.93 cde & $4.46 a b$ & $4.53 \mathrm{ab}$ \\
\hline & 8 days & $3.18 \mathrm{jk}$ & $4.16 \mathrm{~cd}$ & $3.25 \mathrm{ijk}$ & $3.60 \mathrm{fghi}$ & 3.66 efgh & $4.13 \mathrm{~cd}$ & $4.21 \mathrm{bc}$ \\
\hline & 10 days & $3.08 \mathrm{k}$ & $3.53 \mathrm{ghij}$ & $3.24 \mathrm{ijk}$ & 3.34 hijk & 3.37 hijk & 3.50 ghij & 3.57 fghij \\
\hline \multicolumn{9}{|c|}{ Grain yield (t/ha) } \\
\hline \multirow{4}{*}{2011} & $\mathrm{CF}$ & $7.53 \mathrm{fgh}$ & $14.00 \mathrm{a}$ & $8.53 \mathrm{def}$ & $9.66 \mathrm{bc}$ & $10.41 \mathrm{~b}$ & $13.78 \mathrm{a}$ & $14.10 \mathrm{a}$ \\
\hline & 6 days & $7.08 \mathrm{gh}$ & $13.76 \mathrm{a}$ & $7.91 \mathrm{efg}$ & $9.01 \mathrm{~cd}$ & $10.30 \mathrm{~b}$ & $13.50 \mathrm{a}$ & $13.91 \mathrm{a}$ \\
\hline & 8 days & $6.90 \mathrm{ghi}$ & $10.46 \mathrm{~b}$ & 7.76 efg & 8.76 cde & $9.38 \mathrm{bcd}$ & $10.48 \mathrm{~b}$ & $10.50 \mathrm{~b}$ \\
\hline & 10 days & $6.06 \mathrm{i}$ & $10.13 \mathrm{~b}$ & $6.58 \mathrm{hi}$ & 7.95 efg & 8.50 def & $10.08 \mathrm{~b}$ & $10.15 \mathrm{~b}$ \\
\hline \multirow{4}{*}{2012} & CF & $7.41 \mathrm{ghi}$ & $13.91 \mathrm{a}$ & $8.28 \mathrm{efg}$ & $9.66 \mathrm{bcd}$ & $10.56 \mathrm{~b}$ & $13.68 \mathrm{a}$ & $14.25 \mathrm{a}$ \\
\hline & 6 days & 6.96 hij & $13.7 \mathrm{a}$ & $7.78 \mathrm{fgh}$ & $8.95 \mathrm{cdef}$ & $10.18 \mathrm{bc}$ & $13.43 \mathrm{a}$ & $14.00 \mathrm{a}$ \\
\hline & 8 days & 6.46 ij & $10.40 \mathrm{~b}$ & $7.66 \mathrm{fgh}$ & 8.66 defg & 9.30 bcde & $10.41 \mathrm{~b}$ & $10.40 \mathrm{~b}$ \\
\hline & 10 days & $5.96 j$ & $10.05 \mathrm{bc}$ & $6.41 \mathrm{ij}$ & $7.88 \mathrm{fgh}$ & $8.43 \mathrm{efg}$ & $10.01 \mathrm{bc}$ & $\mathrm{bc}$ \\
\hline \multicolumn{9}{|c|}{ Straw yield (t/ha) } \\
\hline \multirow{4}{*}{2011} & CF & 11.81 I & $17.66 \mathrm{a}$ & $12.53 \mathrm{fg}$ & $13.45 \mathrm{de}$ & $14.91 \mathrm{~b}$ & $17.55 \mathrm{a}$ & $17.66 \mathrm{a}$ \\
\hline & 6 days & 11.01 I & $17.40 \mathrm{a}$ & $11.91 \mathrm{gh}$ & 13.10 ef & $14.25 \mathrm{bc}$ & $17.00 \mathrm{a}$ & $17.21 \mathrm{a}$ \\
\hline & 8 days & $10.60 \mathrm{ij}$ & $14.21 \mathrm{bc}$ & $11.65 \mathrm{~h}$ & $12.58 \mathrm{fg}$ & $13.50 \mathrm{de}$ & $14.35 \mathrm{bc}$ & $14.55 \mathrm{bc}$ \\
\hline & 10 days & $9.98 \mathrm{j}$ & $13.48 \mathrm{de}$ & $10.53 \mathrm{ij}$ & $12.03 \mathrm{gh}$ & $12.40 \mathrm{~g}$ & $13.93 \mathrm{~cd}$ & $13.96 \mathrm{~cd}$ \\
\hline \multirow{4}{*}{2012} & $\mathrm{CF}$ & 10.65 hi & $16.85 \mathrm{a}$ & $12.13 \mathrm{efg}$ & 13.10cdef & $14.86 \mathrm{~b}$ & $16.48 \mathrm{a}$ & $16.85 \mathrm{a}$ \\
\hline & 6 days & $10.70 \mathrm{hi}$ & $16.11 \mathrm{a}$ & $11.65 \mathrm{gh}$ & 12.53defg & $13.81 \mathrm{bc}$ & $16.06 \mathrm{a}$ & $16.33 \mathrm{a}$ \\
\hline & 8 days & 9.85 ij & $13.80 \mathrm{bc}$ & $11.60 \mathrm{gh}$ & 12.33defg & 13.31cde & $13.81 \mathrm{bc}$ & $14.08 \mathrm{bc}$ \\
\hline & 10 days & 9.43 j & 13.03cdef & $10.00 \mathrm{ij}$ & $11.91 \mathrm{fg}$ & $12.18 \mathrm{efg}$ & $13.30 \mathrm{cde}$ & $13.45 \mathrm{~cd}$ \\
\hline
\end{tabular}

Means of each factor designated by the same letter are not significantly different at $5 \%$ level of probability according to Duncan's Multiple Rang Test. T1 $=$ Control, T2 $=160 \mathrm{~N}+40 \mathrm{P}+60 \mathrm{~K}, \mathrm{~T} 3=5 \mathrm{t} / \mathrm{ha}$ of compost, T4 $=40 \mathrm{~N}+10 \mathrm{P}+15 \mathrm{~K}+$ compost, $\mathrm{T} 5=80 \mathrm{~N}+20 \mathrm{P}+45 \mathrm{~K}+$ compost, $\mathrm{T} 6=120 \mathrm{~N}+30 \mathrm{P}+45 \mathrm{~K}+$ compost and T7 $=160 \mathrm{~N}+40 \mathrm{P}+60 \mathrm{~K}+$ compost. 


\section{2- Grain quality:}

Results in Table (6) showed that the effect of irrigation intervals on hulling, milling, head rice and broken rice percentages were significant in both seasons. The irrigation systems of continuous flooding and irrigation every 6 days produced the highest numerical values of hulling, milling, head rice percentages without significant differences between them in both seasons. However, irrigation every 10 days produced the lowest values of these characteristics and produced the highest broken rice percentages in both seasons. Similar results were obtained by Ghazy (2010). These results indicated that the decrease in moisture content of grains may be caused a decrease in milling percentage. These results are in harmony with that obtained by Nour et al., (1997) and Ghazy (2010). In this concern, Nour et al., (1994b) reported that grain quality characters such as hulling and head rice percentages were significantly declined as irrigation intervals stepped up to 10 days. Similar results were obtained by Ghazy (2015).

Table (6): Hulling, milling, head rice and broken rice percentage of the tested rice genotypes as affected by irrigation intervals and fertilizer treatments and their interaction in 2011 and 2012 seasons.

\begin{tabular}{|c|c|c|c|c|c|c|c|c|}
\hline \multirow[t]{2}{*}{ Treatment } & \multicolumn{2}{|c|}{ Hulling (\%) } & \multicolumn{2}{|c|}{ Milling (\%) } & \multicolumn{2}{|c|}{ Head rice (\%) } & \multicolumn{2}{|c|}{ Broken rice (\%) } \\
\hline & 2011 & 2012 & 2011 & 2012 & 2011 & 2012 & 2011 & 2012 \\
\hline Irrigation i & & & & & & & & \\
\hline Continu & $78.92 \mathrm{a}$ & $78.13 a$ & $69.70 \mathrm{a}$ & $69.00 \mathrm{a}$ & 63.79a & $62.90 \mathrm{a}$ & $9.67 \mathrm{~d}$ & $9.41 d$ \\
\hline 6 & $78.83 a$ & $78.09 a$ & $69.55 a$ & $68.95 a$ & $63.10 \mathrm{~b}$ & $62.41 \mathrm{~b}$ & $10.93 c$ & $10.68 \mathrm{c}$ \\
\hline $8 c$ & $77.95 b$ & $77.28 \mathrm{~b}$ & $68.97 \mathrm{~b}$ & $68.34 b$ & $62.47 \mathrm{c}$ & $61.84 b$ & $11.51 \mathrm{~b}$ & $11.28 b$ \\
\hline 10 days & $76.72 \mathrm{c}$ & $75.98 \mathrm{c}$ & $68.47 \mathrm{c}$ & $67.69 c$ & $61.47 d$ & $60.89 c$ & $11.70 \mathrm{a}$ & $11.46 \mathrm{a}$ \\
\hline F. test & ** & ** & ** & ** & ** & ** & ** & ** \\
\hline Genotypes (G): & & & & & & & & \\
\hline EHR1 & $78.28 \mathrm{a}$ & $77.49 a$ & $69.29 a$ & 68.57 & $62.88 \mathrm{a}$ & $62.13 a$ & $11.05 b$ & $10.61 b$ \\
\hline SK 2046 H & $77.93 b$ & $77.25 b$ & $69.05 b$ & 68.42 & $62.54 b$ & $61.89 b$ & $10.85 a$ & $10.81 a$ \\
\hline F. test & ** & * & * & N.S & ** & * & ** & ** \\
\hline Fertilizer treatments $(F)$ & & & & & & & & \\
\hline $\mathrm{T} 1$ & $76.27 d$ & $72.23 d$ & $66.45 \mathrm{e}$ & $65.77 \mathrm{e}$ & $61.29 f$ & $60.70 \mathrm{e}$ & $12.00 \mathrm{a}$ & $11.75 a$ \\
\hline T2 & $79.75 a$ & $79.09 a$ & $70.68 a$ & $70.06 \mathrm{a}$ & $63.60 \mathrm{ab}$ & $62.83 \mathrm{a}$ & $10.23 \mathrm{f}$ & $10.00 f$ \\
\hline T3 & $76.55 \mathrm{c}$ & $75.89 \mathrm{c}$ & $67.10 d$ & $66.41 d$ & $61.68 \mathrm{e}$ & $61.12 d$ & $11.83 b$ & $11.47 \mathrm{~b}$ \\
\hline T4 & $77.14 b$ & $76.37 \mathrm{~b}$ & $69.01 \mathrm{c}$ & $68.17 \mathrm{c}$ & $62.27 d$ & $61.54 \mathrm{c}$ & $11.23 \mathrm{c}$ & $10.95 c$ \\
\hline T5 & $77.38 b$ & $76.57 \mathrm{~b}$ & $69.45 b$ & $68.77 b$ & $62.79 \mathrm{c}$ & $62.12 \mathrm{~b}$ & $10.74 d$ & $10.55 d$ \\
\hline T6 & $79.69 a$ & $79.14 a$ & 70.74a & $70.09 \mathrm{a}$ & 63.52b & $62.79 a$ & $10.44 \mathrm{e}$ & $10.25 \mathrm{e}$ \\
\hline T7 & $79.95 a$ & $79.30 \mathrm{a}$ & 70.79a & $70.20 \mathrm{a}$ & $63.83 a$ & $62.97 a$ & $10.20 \mathrm{f}$ & $10.01 \mathrm{f}$ \\
\hline F. test & ** & ** & ** & ** & ** & ** & ** & ** \\
\hline Interactions: & & & & & & & & \\
\hline$I \times V$ & $\mathrm{Ne}$ & N.S & N.S & N.S & N.S & N.S & N.S & N.S \\
\hline$I \times F$ & IV. & N.S & N.S & N.S & N.S & ** & ** & ** \\
\hline$V \times 1$ & $\begin{array}{l}\text { I.S } \\
N . S\end{array}$ & N.S & N.S & N.S & N.S & N.S & N.S & N.S \\
\hline$I \times \vee \times F$ & & N.S & N.S & N.S & N.S & N.S & N.S & N.S \\
\hline
\end{tabular}

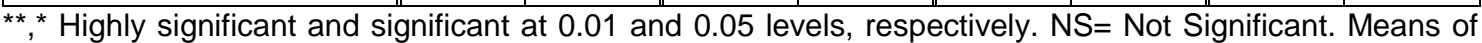
each factor designated by the same letter are not significantly different at $5 \%$ level of probability according to Duncan's Multiple Rang Test. $T 1=$ Control, $T 2=160 \mathrm{~N}+40 \mathrm{P}+60 \mathrm{~K}, \mathrm{~T} 3=5 \mathrm{t} / \mathrm{ha}$ of compost, $\mathrm{T} 4=$ $40 \mathrm{~N}+10 \mathrm{P}+15 \mathrm{~K}+$ compost, $\mathrm{T} 5=80 \mathrm{~N}+20 \mathrm{P}+45 \mathrm{~K}+$ compost, $\mathrm{T} 6=120 \mathrm{~N}+30 \mathrm{P}+45 \mathrm{~K}+$ compost and T7 $=160 \mathrm{~N}+40 \mathrm{P}+60 \mathrm{~K}+$ compost. 
Data in Table (6) showed that EHR1 genotype recorded the highest significant values of hulling, milling and head rice percentages compared to SK2046H genotype in both season. On the other hand, SK2046H genotype recorded the highest significant values of broken rice \% compared to EHR1 genotype in both seasons. These results are in harmony with the results obtained by Ghazy (2010) and Sheta (2010).

Data in Table (6) showed significant effect of fertilizer treatments on hulling, milling, head rice and broken rice percentages in the two seasons. It can be noticed that the plants fertilized with $T_{7}$, followed by $T_{2}$ and $T_{6}$ gave the highest and significant values of hulling, milling and head rice percentages without significant differences among them, while the unfertilized plants $\left(T_{1}\right)$ gave the lowest values of these characters and gave the highest significant values of broken rice (\%) in both seasons. Similar results were obtained by Ghazy (2015).

Data in Table (7) showed that the interaction between irrigation intervals and tested genotypes was highly significant in 2011 season. The plants of EHR1 produced the highest significant values of hulling percentage when they were irrigated under either CF or 6-day systems. However, EHR1 and SK2046H genotypes produced the lowest significant values of hulling (\%), when they were irrigated every 10 days. On the contrary, it can be noticed that the rest tested interactions were not significant on such trait in both seasons. Therefore, their data were excluded.

Data in Table (8) indicated that the interaction between irrigation intervals and fertilizer treatments was highly significant for head rice percentage. Under continuous flooding system plants treated with $T_{7}$ produced the maximum values of head rice percentage followed by $T_{2}$ and $T_{6}$ without significant differences among them. However, plants irrigated every 10 days and control treatment $\left(T_{1}\right)$ gave the lowest values of head rice percentage in 2012 season.

Data in Table (8) indicated that the interaction between irrigation intervals and fertilizer treatments was highly significant for broken rice \% in both seasons. Unfertilized plants $\left(T_{1}\right)$ produced the highest broken rice (\%) under irrigation every 8 and 10 day. However, plants fertilized with $T_{7}$ followed by $\mathrm{T}_{2}$ and $\mathrm{T}_{6}$ produced the lowest broken rice (\%) under continuous flooding system in the two seasons.

\section{3- Chemical analysis}

Data in Table (9) indicated that chemical analysis in milled rice grains (nitrogen, phosphorus, potassium and protein percentages) were significantly affected by irrigation intervals in 2011 and 2012 seasons. Continuous flooding gave the highest values while, irrigation every 10 days gave the lowest values in both seasons.

Table (7): Hulling (\%) as affected by the interaction between irrigation intervals and genotypes in 2011 season.

\begin{tabular}{|c||c|c|c|c|}
\hline \multicolumn{1}{|c||}{} & \multicolumn{4}{c|}{ Irrigation intervals } \\
\cline { 2 - 5 } Genotype & $\begin{array}{c}\text { Continuous } \\
\text { flooding }\end{array}$ & 6 days & 8 days & 10 days \\
\hline \hline EHR1 & $79.15 \mathrm{a}$ & $79.11 \mathrm{a}$ & $78.11 \mathrm{c}$ & $76.73 \mathrm{e}$ \\
SK2046 H & $78.69 \mathrm{~b}$ & $78.54 \mathrm{~b}$ & $77.78 \mathrm{c}$ & $76.71 \mathrm{e}$ \\
\hline
\end{tabular}

Means of each factor designated by the same letter are not significantly different at $5 \%$ level of probability according to Duncan's Multiple Rang Test 
Ibrahim, et al.,

Table (8): Head and broken rice (\%) as affected by the interaction between irrigation intervals and fertilizer treatment.

\begin{tabular}{|c|c|c|c|c|c|}
\hline \multirow[b]{2}{*}{ Season } & \multirow[b]{2}{*}{$\begin{array}{l}\text { Fertilizer } \\
\text { treatments }\end{array}$} & \multicolumn{4}{|c|}{ Irrigation intervals } \\
\hline & & $\begin{array}{l}\text { Continuous } \\
\text { flooding }\end{array}$ & 6 days & 8 days & 10 days \\
\hline \multicolumn{6}{|c|}{ Head rice (\%) } \\
\hline 2012 & $\begin{array}{l}\text { T1 } \\
\text { T2 } \\
\text { T3 } \\
\text { T4 } \\
\text { T5 } \\
\text { T6 } \\
\text { T7 }\end{array}$ & $\begin{array}{c}61.00 \mathrm{hij} \\
64.08 \mathrm{ab} \\
61.66 \mathrm{ghi} \\
62.16 \mathrm{efg} \\
63.50 \mathrm{abcd} \\
63.75 \mathrm{abc} \\
64.16 \mathrm{a}\end{array}$ & $\begin{array}{l}61.00 \mathrm{hij} \\
63.16 \mathrm{~cd} \\
61.33 \mathrm{ghi} \\
61.91 \mathrm{fgh} \\
62.66 \mathrm{def} \\
63.25 \mathrm{bcd} \\
63.58 \mathrm{abcd}\end{array}$ & $\begin{array}{c}60.83 \mathrm{ij} \\
62.66 \mathrm{def} \\
61.16 \mathrm{hij} \\
61.25 \mathrm{ghij} \\
61.41 \mathrm{ghi} \\
62.75 \mathrm{def} \\
62.83 \mathrm{de}\end{array}$ & $\begin{array}{c}60.00 \mathrm{k} \\
61.41 \mathrm{ghi} \\
60.33 \mathrm{jk} \\
60.83 \mathrm{ij} \\
60.91 \mathrm{hij} \\
61.41 \mathrm{ghi} \\
61.33 \mathrm{ghi}\end{array}$ \\
\hline \multicolumn{6}{|c|}{ Broken rice (\%) } \\
\hline 2011 & $\begin{array}{l}\text { T1 } \\
\text { T2 } \\
\text { T3 } \\
\text { T4 } \\
\text { T5 } \\
\text { T6 } \\
\text { T7 }\end{array}$ & $\begin{array}{l}10.06 \mathrm{j} \\
9.35 \mathrm{kl} \\
10.00 \mathrm{j} \\
10.08 \mathrm{j} \\
9.58 \mathrm{k} \\
9.38 \mathrm{kl} \\
9.23 \mathrm{l}\end{array}$ & $\begin{array}{c}12.08 \mathrm{c} \\
10.16 \mathrm{j} \\
11.88 \mathrm{~cd} \\
11.36 \mathrm{ef} \\
10.73 \mathrm{hi} \\
10.23 \mathrm{j} \\
10.08 \mathrm{j}\end{array}$ & $\begin{array}{c}12.86 \mathrm{ab} \\
10.66 \mathrm{hi} \\
12.63 \mathrm{~b} \\
11.66 \mathrm{de} \\
11.20 \mathrm{fg} \\
11.00 \mathrm{gh} \\
10.60 \mathrm{i}\end{array}$ & $\begin{array}{c}12.98 \mathrm{a} \\
10.75 \mathrm{hi} \\
12.83 \mathrm{ab} \\
11.83 \mathrm{~cd} \\
11.45 \mathrm{ef} \\
11.16 \mathrm{fg} \\
10.91 \mathrm{ghi}\end{array}$ \\
\hline 2012 & $\begin{array}{l}\text { T1 } \\
\text { T2 } \\
\text { T3 } \\
\text { T4 } \\
\text { T5 } \\
\text { T6 } \\
\text { T7 }\end{array}$ & $\begin{array}{l}9.73 \mathrm{kl} \\
9.06 \mathrm{~m} \\
9.66 \mathrm{kl} \\
9.83 \mathrm{kl} \\
9.41 \mathrm{~lm} \\
9.18 \mathrm{~m} \\
9.03 \mathrm{~m}\end{array}$ & $\begin{array}{c}11.91 \mathrm{~cd} \\
9.91 \mathrm{kl} \\
11.55 \mathrm{de} \\
11.03 \mathrm{efgh} \\
10.45 \mathrm{ij} \\
10.11 \mathrm{jk} \\
9.83 \mathrm{kl}\end{array}$ & $\begin{array}{c}12.50 \mathrm{ab} \\
10.50 \mathrm{hij} \\
12.25 \mathrm{bc} \\
11.41 \mathrm{ef} \\
11.10 \mathrm{efg} \\
10.78 \mathrm{ghi} \\
10.46 \mathrm{ij}\end{array}$ & $\begin{array}{c}12.86 \mathrm{a} \\
10.55 \mathrm{hij} \\
12.41 \mathrm{~b} \\
11.55 \mathrm{de} \\
11.25 \mathrm{efg} \\
10.91 \mathrm{fghi} \\
10.71 \mathrm{ghi}\end{array}$ \\
\hline
\end{tabular}

Means of each factor designated by the same letter are not significantly different at $5 \%$ level of probability according to Duncan's Multiple Rang Test. T1 $=$ Control, T2 $=160 \mathrm{~N}+40 \mathrm{P}+60 \mathrm{~K}, \mathrm{~T} 3=5 \mathrm{t} / \mathrm{ha}$ of compost, T4 $=40 \mathrm{~N}+10 \mathrm{P}+15 \mathrm{~K}+$ compost, $\mathrm{T} 5=80 \mathrm{~N}+20 \mathrm{P}+45 \mathrm{~K}+$ compost, $\mathrm{T} 6=120 \mathrm{~N}+30 \mathrm{P}+45 \mathrm{~K}+$ compost and $\mathrm{T} 7$ $=160 \mathrm{~N}+40 \mathrm{P}+60 \mathrm{~K}+$ compost.

Data in Table (9) indicated that EHR1 genotype recorded the highest significant values of phosphorus and potassium percentages compared to SK2046H genotype in both seasons. Similar results were reported by Nour et al (1994b) .

Data in Table (9) indicated that nitrogen, phosphorus, potassium and protein percentages were significantly affected by the tested fertilizer treatments in the two seasons. The application of $T_{7}, T_{2}$ and $T_{6}$ gave the highest values of nitrogen, phosphorus, potassium and protein (\%) without significant differences among them in both seasons. However, the unfertilized plants (T1) gave the lowest values in both seasons. Similar results were reported by Hashem (2010).

The results in Table (9) show that the first and second order interactions among the three tested factors under this experiment on nitrogen, phosphorus, potassium and protein (\%) were not significant in both seasons. Consequently, their data were neglected. 
Table (9): Nitrogen, phosphorus, potassium and protein percentages in milled grains of the two tested rice genotypes as affected by irrigation intervals and fertilizer treatments and their interactions in 2011 and 2012 seasons.

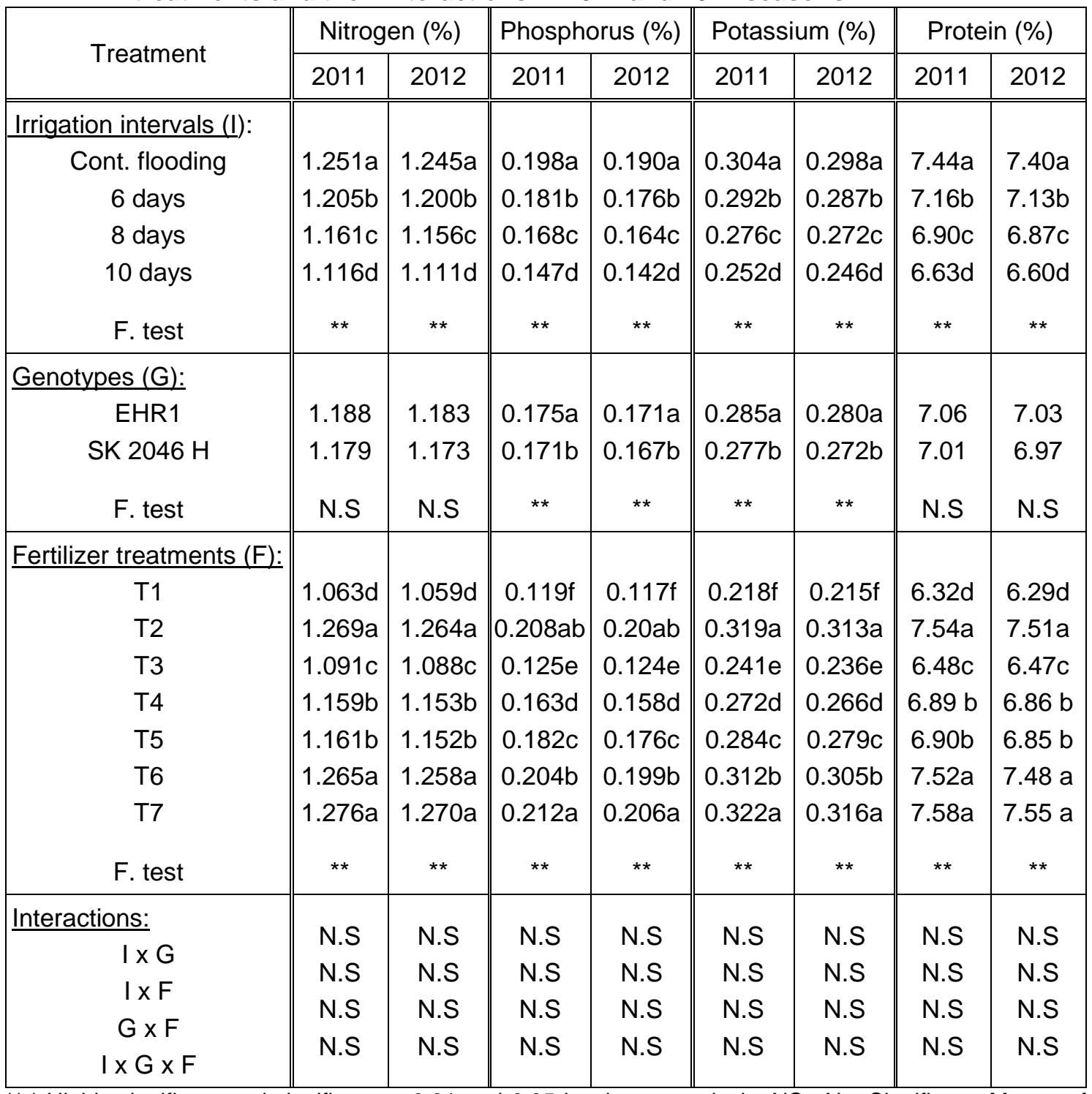

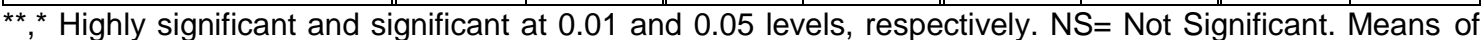
each factor designated by the same letter are not significantly different at $5 \%$ level of probability according to Duncan's Multiple Rang Test. $T 1=$ Control, $T 2=160 \mathrm{~N}+40 \mathrm{P}+60 \mathrm{~K}, \mathrm{~T} 3=5 \mathrm{t} / \mathrm{ha}$ of compost, $\mathrm{T} 4=$ $40 \mathrm{~N}+10 \mathrm{P}+15 \mathrm{~K}+$ compost, $\mathrm{T} 5=80 \mathrm{~N}+20 \mathrm{P}+45 \mathrm{~K}+$ compost, $\mathrm{T} 6=120 \mathrm{~N}+30 \mathrm{P}+45 \mathrm{~K}+$ compost and T7 $=160 \mathrm{~N}+40 \mathrm{P}+60 \mathrm{~K}+$ compost.

\section{4- Water relations:}

The amount of irrigation water used $\left(\mathrm{m}^{3} / \mathrm{ha}\right)$ at different growth periods as well as water saved percentage are presented in Table (10). The amount of water input (before starting irrigation treatments) for land preparation of both nursery and permanent field ,thirty days and through ten days after transplanting and before irrigation treatments application were 3071.5 and $3000.5 \mathrm{~m}^{3} / \mathrm{ha}$ in 2011 and 2012 seasons, respectively, (Table, 8). The previous period (forty days) was considered a blank for all treatments. In this concern, Nour et al., (1994a) reported that the amount of water 
used in land preparation for transplanting rice amounted to $4525.5 \mathrm{~m}^{3} / \mathrm{h}$.

Data in Table (10) show the amount of irrigation water used $\left(\mathrm{m}^{3} / \mathrm{ha}\right)$ at different stages, i.e. (1) before starting of irrigation treatments (about 40 days) for land preparation of both nursery and permanent field (30 days) and after transplanting (10 days), (2) 10 days after transplanting till heading (about 60 days) and (3) from heading till maturity. The data showed that increasing irrigation intervals from continuous flooding up to irrigation every 6 , 8 and 10 days tended to decrease the amount of water used from (14276 and $\left.14190 \mathrm{~m}^{3} / \mathrm{ha}\right)$ to $\left(12873\right.$ and $\left.12721 \mathrm{~m}^{3} / \mathrm{ha}\right)$, (11885 and $11722 \mathrm{~m}^{3} / \mathrm{ha}$ ) and (10630 and $10579 \mathrm{~m}^{3} / \mathrm{ha}$ ) in the first and second seasons, respectively. The variations in the amounts of irrigation water input obtained herein may be due to the differences in subsurface draining systems between the irrigation treatments as well as the experimental sites.

From these results, it can be noticed that the continuous flooding irrigation received the highest amount of water used throughout both seasons, as expected, while, the lowest amounts were received by irrigation every 10 days interval. Similar results were obtained by El-Refaee et al (2006) who found that the amounts of irrigation water used for the continuous flooding irrigation system in rice field was higher than that of the other irrigation systems. The data in Table (10) show that increasing of irrigation intervals up to 6,8 and 10 days saved irrigation water by 9.82 , 16.74 and $25.53 \%$ in the first season and $10.35,17.39$ and $25.44 \%$ in the second season as compared with the continuous flooding irrigation system, respectively.

The results in Table (11) showed that the values of water productivity were significantly affected by the tested irrigation systems in both seasons. Irrigation every 6 days recorded the maximum values $(0.832$ and $0.837 \mathrm{~kg} / \mathrm{m}^{3}$ ) in the first and second seasons, respectively, followed by 10-day, CF and 8-day without significant differences between them in both seasons. Data in Table (11) indicated that EHR1 genotype produced the highest and significant values of water productivity $\left(0.800 \mathrm{~kg} / \mathrm{m}^{3}\right)$ compared with $\mathrm{SK} 2046 \mathrm{H}$ genotype $(0.785$ $\mathrm{kg} / \mathrm{m}^{3}$ ) in 2012 season.

Table (10): The amount of water used ( $\mathrm{m}^{3} / \mathrm{ha}$ ) and water saved $\%$ as affected by different irrigation treatment through 2011 and 2012 seasons.

\begin{tabular}{|c||c|c|c|c||c|c|c|c|}
\hline \multicolumn{1}{|c||}{ Periods } & \multicolumn{3}{|c||}{2011} & \multicolumn{4}{c|}{2012} \\
\cline { 2 - 9 } & $\begin{array}{c}\text { Cont. } \\
\text { flooding }\end{array}$ & 6 days & 8 days & 10 days & $\begin{array}{c}\text { Cont. } \\
\text { flooding }\end{array}$ & 6 days & 8 days & 10 days \\
\hline $\begin{array}{c}\text { Before irrigation } \\
\text { treatments } \\
\text { (about 40 days) }\end{array}$ & 3071.5 & 3071.5 & 3071.5 & 3071.5 & 3000.5 & 3000.5 & 3000.5 & 3000.5 \\
\hline $\begin{array}{c}\text { 10 days after } \\
\text { transplanting till heading } \\
\text { (about 60 days) }\end{array}$ & 6516.9 & 5331.5 & 4923 & 4408 & 6649 & 5390.5 & 4961.5 & 4518.5 \\
\hline $\begin{array}{c}\text { From heading till } \\
\text { maturity } \\
\text { (about 35 days) }\end{array}$ & 4687.6 & 4470 & 3890.5 & 3150.5 & 4540.5 & 4330 & 3760 & 3060 \\
\hline Total water used (m ${ }^{3} /$ ha) & 14276 & 12873 & 11885 & 10630 & 14190 & 12721 & 11722 & 10579 \\
\hline Total water saved \% & - & 9.82 & 16.74 & 25.53 & - & 10.35 & 17.39 & 25.44 \\
\hline
\end{tabular}


Table (11): Water productivity ( $\mathrm{kg}$ grains $/ \mathrm{m}^{3}$ ) of the two tested rice genotypes as affected by irrigation intervals and fertilizer treatments and their interaction in 2011 and 2012 seasons.

\begin{tabular}{|c|c|c|}
\hline \multirow{2}{*}{ Treatment } & \multicolumn{2}{|c|}{ Water productivity $\left(\mathrm{kg} / \mathrm{m}^{3}\right)$} \\
\hline & 2011 & 2012 \\
\hline \multicolumn{3}{|l|}{ Irrigation intervals (I): } \\
\hline Continuous flooding & $0.777 \mathrm{~b}$ & $0.777 \mathrm{~b}$ \\
\hline Irrigation every 6 days & $0.832 \mathrm{a}$ & $0.837 \mathrm{a}$ \\
\hline Irrigation every 8 days & $0.767 \mathrm{~b}$ & $0.766 \mathrm{~b}$ \\
\hline Irrigation every 10 days & $0.795 \mathrm{~b}$ & $0.789 \mathrm{~b}$ \\
\hline F. test & * & * \\
\hline \multicolumn{3}{|l|}{ Genotypes (G): } \\
\hline EHR1 & 0.799 & $0.800 \mathrm{a}$ \\
\hline SK $2046 \mathrm{H}$ & 0.787 & $0.785 b$ \\
\hline F. test & N.S & * \\
\hline \multicolumn{3}{|l|}{ Fertilizer treatments $(F):$} \\
\hline Control (T1) & $0.552 \mathrm{e}$ & $0.542 \mathrm{e}$ \\
\hline $160 \mathrm{~N}+40 \mathrm{P}+60 \mathrm{~K}(\mathrm{~T} 2)$ & $0.967 \mathrm{a}$ & $0.968 \mathrm{a}$ \\
\hline $5 \mathrm{t} / \mathrm{ha}$ of compost (T3) & $0.617 d$ & $0.609 \mathrm{~d}$ \\
\hline $40 \mathrm{~N}+10 \mathrm{P}+15 \mathrm{~K}+$ compost $(\mathrm{T} 4)$ & $0.710 \mathrm{c}$ & $0.711 \mathrm{c}$ \\
\hline $80 \mathrm{~N}+20 \mathrm{P}+30 \mathrm{~K}+$ compost (T5) & $0.774 \mathrm{~b}$ & $0.778 \mathrm{~b}$ \\
\hline $120 \mathrm{~N}+30 \mathrm{P}+45 \mathrm{~K}+$ compost (T6) & $0.957 \mathrm{a}$ & $0.958 \mathrm{a}$ \\
\hline $160 \mathrm{~N}+40 \mathrm{P}+60 \mathrm{~K}+$ compost (T7) & 0.972 a & $0.980 \mathrm{a}$ \\
\hline F. test & ** & ** \\
\hline \multicolumn{3}{|l|}{ Interactions: } \\
\hline$I \times G$ & N.S & N.S \\
\hline $\mathrm{I} \times \mathrm{F}$ & $* *$ & $* *$ \\
\hline$G \times F$ & N.S & N.S \\
\hline$I \times G \times F$ & N.S & N.S \\
\hline
\end{tabular}

**, ${ }^{*}$ Highly significant and significant at 0.01 and 0.05 levels, respectively. NS= Not Significant. Means of each factor designated by the same letter are not significantly different at $5 \%$ level of probability according to Duncan's Multiple Rang Test.

Data in Table (11) showed that there was a significant effect among the different tested fertilizer treatments on the values of water productivity in both seasons. The maximum significant values of water productivity were obtained by the plants fertilized with $T_{7}, T_{2}$ and $T_{6}$ in a descending order without significant differences among them in both seasons. However, the unfertilized plants $\left(T_{1}\right)$ had the minimum values in both seasons.
The interaction between irrigation system and fertilizer treatments was significant for the values of water productivity in both seasons (Table 12). Generally, the highest significant values were obtained from the plants fertilized with $T_{7}, T_{2}$ and $T_{6}$ under the irrigation every 6 days without significant differences among them in both seasons. However, plants irrigated by continuous flooding and unfertilized $\left(T_{1}\right)$ gave the lowest values of water productivity in both seasons. 
Table (12): Water productivity ( $\mathrm{kg}$ grains $/ \mathrm{m}^{3}$ water) as influenced by the interaction between irrigation intervals and fertilizer treatments during 2011 and 2012 seasons.

\begin{tabular}{|c|c|c|c|c|c|c|c|c|}
\hline \multirow{3}{*}{$\begin{array}{l}\text { Fertilizer } \\
\text { treatments }\end{array}$} & \multicolumn{8}{|c|}{ Irrigation intervals } \\
\hline & \multicolumn{4}{|c|}{2011} & \multicolumn{4}{|c|}{2012} \\
\hline & $\begin{array}{c}\text { Cont. } \\
\text { flooding }\end{array}$ & 6-day & 8-day & 10-day & $\begin{array}{l}\text { Cont. } \\
\text { flooding }\end{array}$ & 6-day & 8-day & 10-day \\
\hline T1 & $0.521 \mathrm{~m}$ & $0.546 \mathrm{Im}$ & $0.575 \mathrm{klm}$ & $0.566 \mathrm{klm}$ & $0.518 \mathrm{k}$ & $0.545 \mathrm{k}$ & $0.548 \mathrm{k}$ & $0.556 \mathrm{jk}$ \\
\hline $\mathrm{T} 2$ & $0.978 \mathrm{bc}$ & $1.06 \mathrm{a}$ & $0.876 \mathrm{de}$ & $0.950 \mathrm{~cd}$ & 0.975 cde & $1.07 \mathrm{ab}$ & $0.883 e f$ & $0.945 \mathrm{de}$ \\
\hline T3 & $0.595 \mathrm{jklm}$ & $0.61 \mathrm{ijklm}$ & 0.648hijk & $0.616 \mathrm{ijkl}$ & $0.578 \mathrm{ijk}$ & $0.606 \mathrm{ijk}$ & 0.650 hig & $0.601 \mathrm{ijk}$ \\
\hline $\mathrm{T} 4$ & $0.671 \mathrm{ghij}$ & 0.691ghi & $0.733 \mathrm{fgh}$ & $0.743 \mathrm{fg}$ & $0.676 \mathrm{hi}$ & $0.696 \mathrm{ghi}$ & $0.733 \mathrm{gh}$ & $0.738 \mathrm{gh}$ \\
\hline T5 & $0.728 \mathrm{fgh}$ & 0.795 ef & $0.781 \mathrm{f}$ & 0.791 ef & $0.738 \mathrm{gh}$ & $0.795 f g$ & $0.788 \mathrm{fg}$ & $0.793 \mathrm{fg}$ \\
\hline T6 & $0.963 \mathrm{bcd}$ & $1.04 \mathrm{ab}$ & $0.876 \mathrm{de}$ & $0.945 \mathrm{~cd}$ & $0.958 \mathrm{de}$ & $1.05 \mathrm{ab}$ & 0.883 ef & $0.941 \mathrm{de}$ \\
\hline T7 & $0.985 \mathrm{bc}$ & $1.07 \mathrm{a}$ & $0.878 \mathrm{de}$ & $0.951 \mathrm{~cd}$ & $0.998 \mathrm{bcd}$ & $1.09 \mathrm{a}$ & 0.880 ef & $0.946 \mathrm{de}$ \\
\hline
\end{tabular}

Means of each factor designated by the same letter are not significantly different at $5 \%$ level of probability according to Duncan's Multiple Rang Test. T1 $=$ Control, T2 $=160 \mathrm{~N}+40 \mathrm{P}+60 \mathrm{~K}, \mathrm{~T} 3=5 \mathrm{t} / \mathrm{ha}$ of compost, T4 $=40 \mathrm{~N}+10 \mathrm{P}+15 \mathrm{~K}+$ compost, $\mathrm{T} 5=80 \mathrm{~N}+20 \mathrm{P}+45 \mathrm{~K}+$ compost, $\mathrm{T} 6=120 \mathrm{~N}+30 \mathrm{P}+45 \mathrm{~K}+$ compost and $\mathrm{T} 7$ $=160 \mathrm{~N}+40 \mathrm{P}+60 \mathrm{~K}+$ compost.

Finally, It can be concluded that using the irrigation system every 6 days with the application of mineral fertilizer of $120 \mathrm{Kg} \mathrm{N}+$ $30 \mathrm{Kg} \mathrm{P}_{2} \mathrm{O}_{5}+45 \mathrm{~kg} \mathrm{~K}_{2} \mathrm{O} / \mathrm{ha}+$ organic fertilizer of 5 ton compost / ha can be saved about $10 \%$ of the amounts of irrigation water as well as $25 \%$ of mineral fertilizer of NPK with insignificant reduction in grain productivity of hybrid rice genotypes.

\section{REFERENCES}

A.O.A.C. (1970). Official Methods of Analysis. $11^{\text {th }}$ Ed. Washington, D.C., USA.

Aulakh, M. S. and B. Singh. (1997). Nitrogen losses and fertilizer nitrogen use efficiency in irrigated porous soils. Nutrient Cycling in Agroecosystem 7:116. (C.F computer search)

Bastawisi, A. O., I. R. Aidy; H. F. El-Mowafi and M. A. Maximos (1998). Research and development for hybrid rice technology in Egypt .In: Virmani, S.S., Siddiq E.A., Muralidharan K., editors. Advances in hybrid rice technology. Proceedings of the $3^{\text {rd }}$ International symposium , 14-16 Nov. 1996. Hyderabad, India, Manila (Philippines).
International Rice Research Institute, pp: 367-372.

Bastawisi, A. O., H. F. El-Mowafi, M. I. Abouyossef, A. E. Draz, I. R. Aidy, S. A. Ghanem, A. A. El-Kady, M. F. Sabaa, M. A. Maximos, and A. T. Badawi (2005). Hybrid rice technology in Egypt. Egypt. J. Res., 83(5A): 47-60.

Dobermann, A. and T. H. Fairhurst (2002). Rice straw management. Better crops international 16:7-9, Special Supplement.

Duncan, B. (1955). Multiple Range and Multiple F. test. Biometrics, 11: 1-42.

El-Refaee, I. S. (2012). Effect of application of rice straw compost and NPK fertilizers under some irrigation regimes on grain yield and water productivity of EHRI hybrid rice cultivar. J. Plant Production. Mansoura Univ., 3 (3):445-462.

El-Refaee, I. S. (2002). Studies on irrigation systems for some rice cultivars. Ph.D. Thesis, Agron. Dept., Fac. of Agric., Kafr El-Sheikh, Tanta Univ., Egypt.

El-Refaee, I. S., R. A. Ebaid and I. M. ElRewiny (2006). Performance of rice (Oryza sativa L.) plant under different water regimes and methods of planting. Alex. J. Agric. Res., 51 (2): 47-55. 
El-Saka, Mai A. (2013). Performance of Egyptian hybrid rice one under some irrigation intervals and different fertilizer treatments. M.Sc. Thesis, Fac. of Agric., Kafrelsheikh Univ., Egypt.

FFTC publication database .(1998). Food and Fertilizer Technology center ,Taiwan Microbial and Organic fertilizer in Asia .

Ghazy. Hasnaa A. (2010). Effect of different irrigation treatments and harvest time on hybrid rice productivity. M.Sc. Thesis, Fac. of Agric. Kafr El-Sheikh, Univ, Egypt.

Ghazy. Hasnaa A. (2015). Response of rice crop to organic and mineral fertilization under different irrigation regimes .Ph.D. Thesis, Fac. of Agric., Kafr El-Sheikh, Univ, Egypt.

Gomez, K. A. and A. A. Gomez (1984). Statistical procedures for Agricultural Researches. $2^{\text {nd }}$ Ed., John Wiley \&Sons., USA.

Hashem, I. M. M. (2010). Fertilization of hybrid rice plants grown under Egyptian alluvial soil conditions. Ph.D. Thesis, Fac. Agric., Mansoura Univ., Egypt.

Jackson, M. L. (1967). Soil chemical analysis. Printic Hall of India, New Delhi, 144-197.

Juliano, B. O. (1971). A simplified assay for milled rice amylose. Cereal Sci. Today, (16):334-338,340-360.

Khush, G. S. C. M. Paule and N. M. Dela Cruze (1979). Rice grain quality evaluation and improvement at IRRI. Proc. Workshop on chemical Aspects of Rice Grain Quality. IRRI, Manila, Philippines. 16 (5):28.

Nour, M. A. M., A. E. Abd El-Wahab, A. A. El-Kady and R. A. Ebaid (1997). Productivity of some rice cultivars under different irrigation intervals and potassium levels. Egypt, J. Appl. Sci., 12 (6):137-154.

Nour, M. A., A. E. Abd El-Wahab, and E. N. Mahrous (1994a). Effect of water stress at different growth stage on rice yield and contributing variables. Agric. Sci. Mansoura Univ. 19 (2):403-412.

Nour, M. A., A. E. Abd El-Wahab and S. A. Ghanem (1994b). Broadcast-seeded rice as affected by different irrigation intervals. Egypt, J. Appl. Sci. 9 (8):671683.

Prasad, B. and S. K. Sinha (2000). Longterm effects fertilizer and organic manures on crop yields, nutrient balance, and soil properties in rice - wheat cropping system in Bihar. PP: 105-119. In : long -term soil fertility experiments in rice-wheat cropping system (Abrol, L.P.:Bronson, K. F. :Duxbury, J. M. And Gupta, R. K. eds.). Rice - wheat consortium paper series 6. New Delhi, India :Rice-Wheat Consortium for the Indo- Gangetic Plains.

Raikar, S. D. (2007). Studies on organics and integrated nutrients on seed production and storability of scented rice Cv. Mugad Sugandha. Ph.D. Thesis Submitted to the University of Agricultural Sciences, Dharwad, India. (C.F Computer Search).

Sheta, I. A. (2010). Effect of planting methods and Nitrogen levels on the productivity of some hybrids and inbred rice cultivars. M.Sc. Thesis, Fac. of Agric. Kafr El- Sheikh Univ., Egypt.

Siavoshi, M., A. Nasiri and S. L. Laware (2011). Effect of organic fertilizer on growth and yield components in rice (Oryza sativa L.). J. of Agric. Sci., 3 (3): 217-224.

Tuong , T. P. and B. A. M. Bouman (2003). Rice production in water - scarce environments. In: Kijine , J.W.: Barker, R.: Molden, D. (Eds.), Water productivity in Agriculture: Limits and Opportunities for improvement. CABI Publishing, UK, 53-67.

Watanable, F. S. and S. A. Olsen (1965). Calorimetric determination of phosphorus in water extract. Soil Sci., 93:183-188. 


\section{Ibrahim, et al.,}

\section{تأثير فترات الرى ونظم التسميد العضوى والمعدنى على إنتاجية وجودة الأرز الهجين}

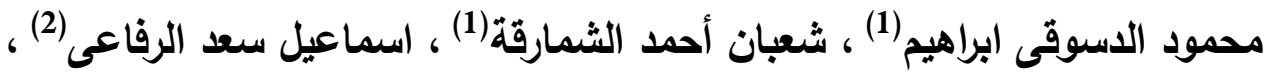

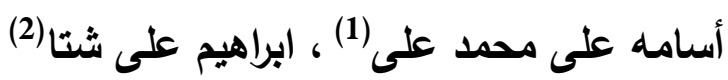

(1) قسم المحاصيل- كلية الزراعة - شبين الكوم - جامعة المنوفية

(2) مركز البحوث و التدريب في الأرز - معهد بحوث المحاصيل الحقلية - مركز البحوث الزراعية - سخا- كفر الثيخ الثيخ

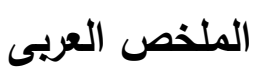

أجريت تجربتان حقليتان بالمزرعة البحثية لمركز البحوث والتدريب فى الأرز بسخا - كفر الثيخ - مصر خلال موسمى

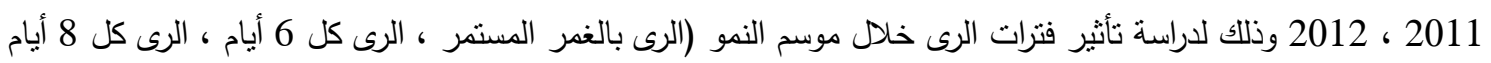

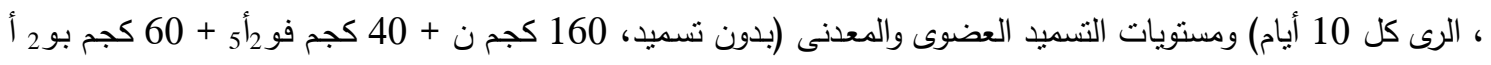

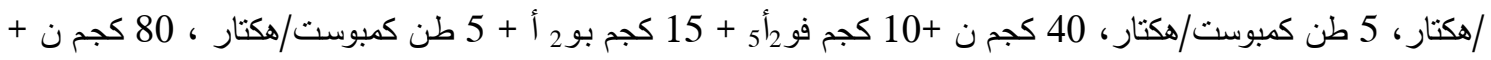

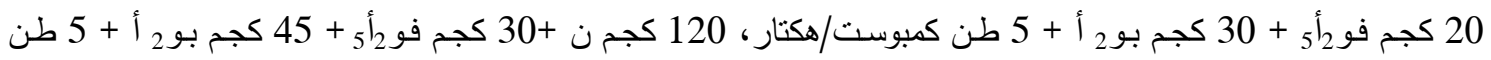

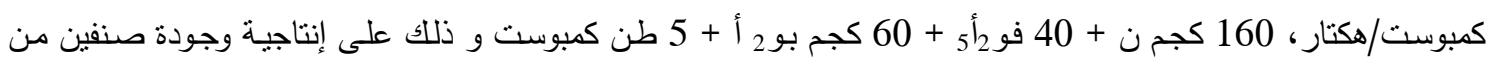

اصناف الأرز الهجين (هجين مصرى 1، هجين SK2046 H) ويمكن تلخيص أهم النتائج على النحو التالى:

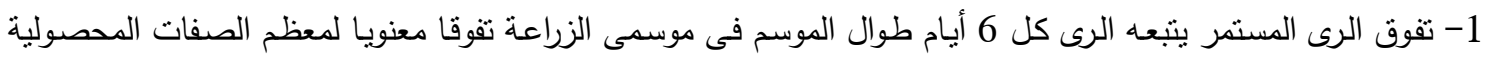

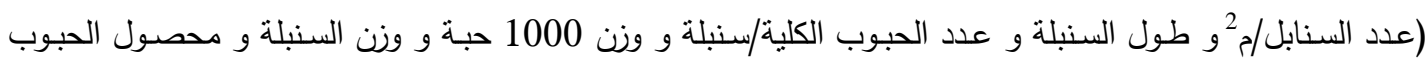

والقش) صفات جودة الحبوب (النسبة المئويـة لكل من التقتير و النتييض و الحبوب السليمة) و كذللك لقيم التحليل

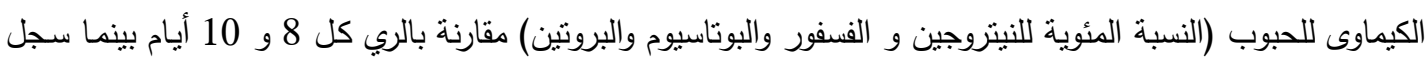

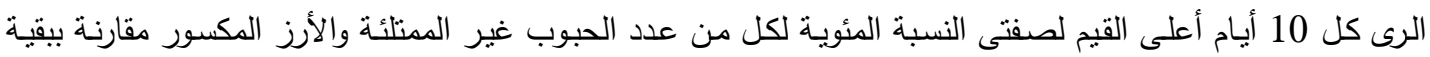

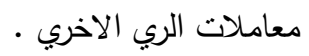

2- تفوق الهجين مصرى تفوقا معنويا فى معظم صفات المحصول وجودة الحبوب وكذلك التحليل الكيماوى للحبوب بينما

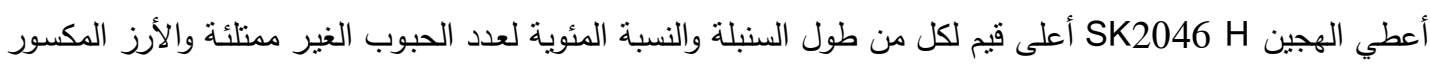

$$
\text { خلال موسمى الزراعة. }
$$

3- ادى التسميد بالمعدلات (160 كجم ن + 40 فو وأك + 60 كجم بور أ + 5 طن كمبوست/هكتار) و و 160 كجم ن +

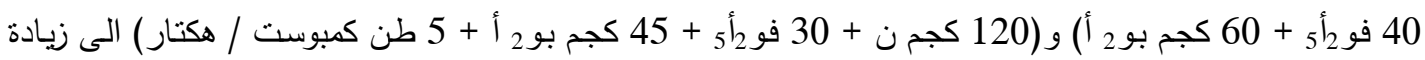

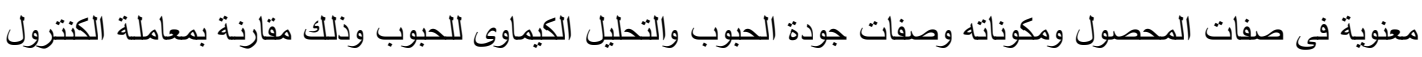

$$
\text { (بدون تسميد) خلال موسمى الزراعة. }
$$

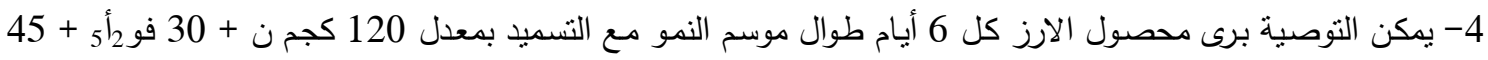

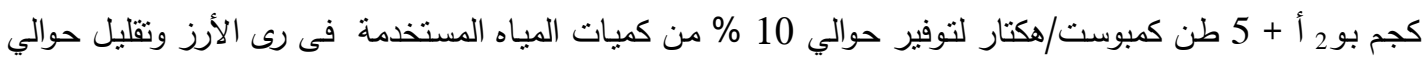
25 \% من كميات الأسمدة المعدنية المستخدمة دون حدوث نقص معنو منوى في انتاجية محصول الحبوب لصنفى الارز

$$
\text { الهجين المختبرة. }
$$


Effect of irrigation intervals and organic and mineral fertilization systems on ...... 